\title{
On the similarities and differences between the products of oxidation of hydrocarbons under simulated atmospheric conditions and cool-
} 5 flames.

Fig. S1, $\mathrm{CH}_{2}$ - Kendrick mass defect plots, DBE: 1-4

Fig. S2, $\mathrm{CH}_{2}-$ Kendrick mass defect plots, DBE: 5-8

10 Fig. S3, $\mathrm{CH}_{2}$ - Kendrick mass defect plots, DBE: 9-11

Fig. S4, examples of reaction mechanisms for the formation of KHPs from limonene and all the reaction sites of limonene that can give KHPs (18 isomers in total).

Fig. S5, all 18 isomers potentially formed by oxidation from the radical $\mathrm{OH}^{*}$

Fig. S6, UHPLC spectrum of the compound $\mathrm{C}_{16} \mathrm{H}_{18} \mathrm{O}_{6} \mathrm{~N}_{4}$ from the reaction of KHPs with 2,4-DNPH, inset: increase of the line

15 intensity to 9.71 min depending on the reaction time with DNPH.

Fig. S7, comparison of UHPLC profiles of diketones and KHPs. a) UHPLC KHPs with diketones extracted from the MS/MS of the KHP, b) diketones UHPLC profile.

Fig $\mathrm{S} 8$, Comparison of the UHPLC profile (negative APCI mode) of $\mathrm{C}_{10} \mathrm{H}_{16} \mathrm{O}_{2}$ isomers from the Waddington mechanism with that obtained by the addition of DNPH. 

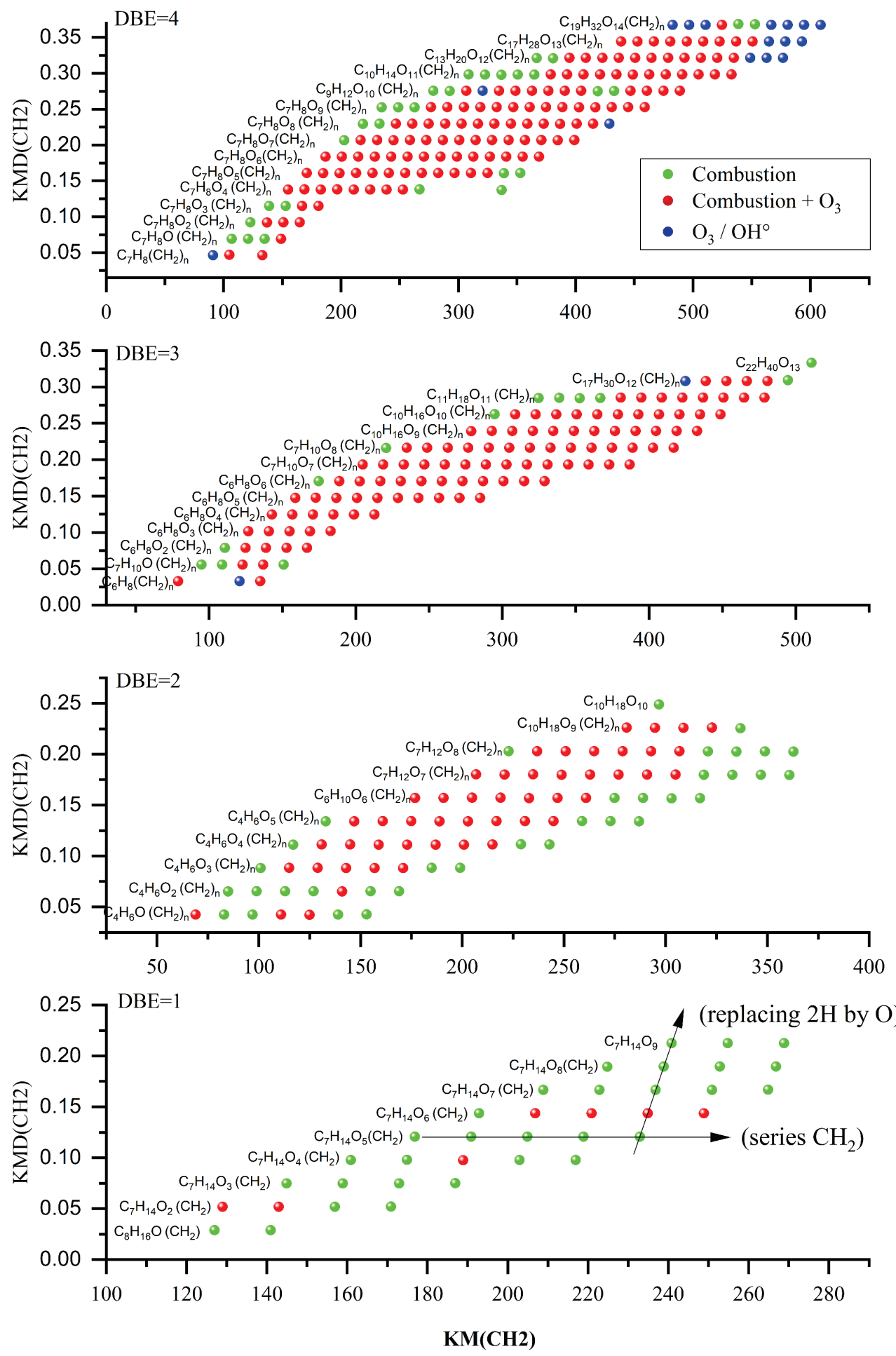

SI Figure 1. $\mathrm{CH}_{2}-$ Kendrick mass defect plots, DBE: 1-4 

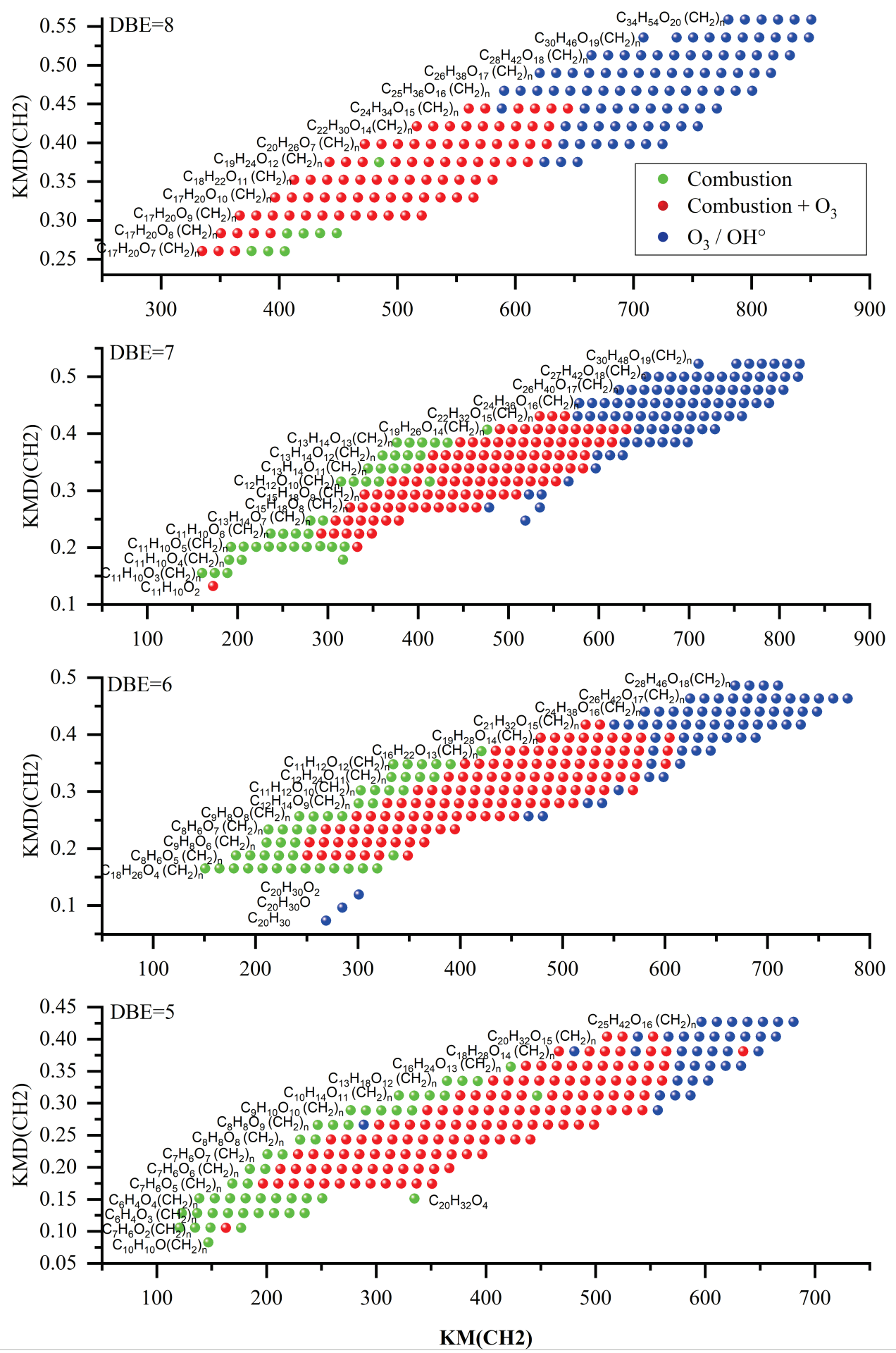

SI Figure 2. $\mathrm{CH}_{2}$ - Kendrick mass defect plots, DBE: 5-8 

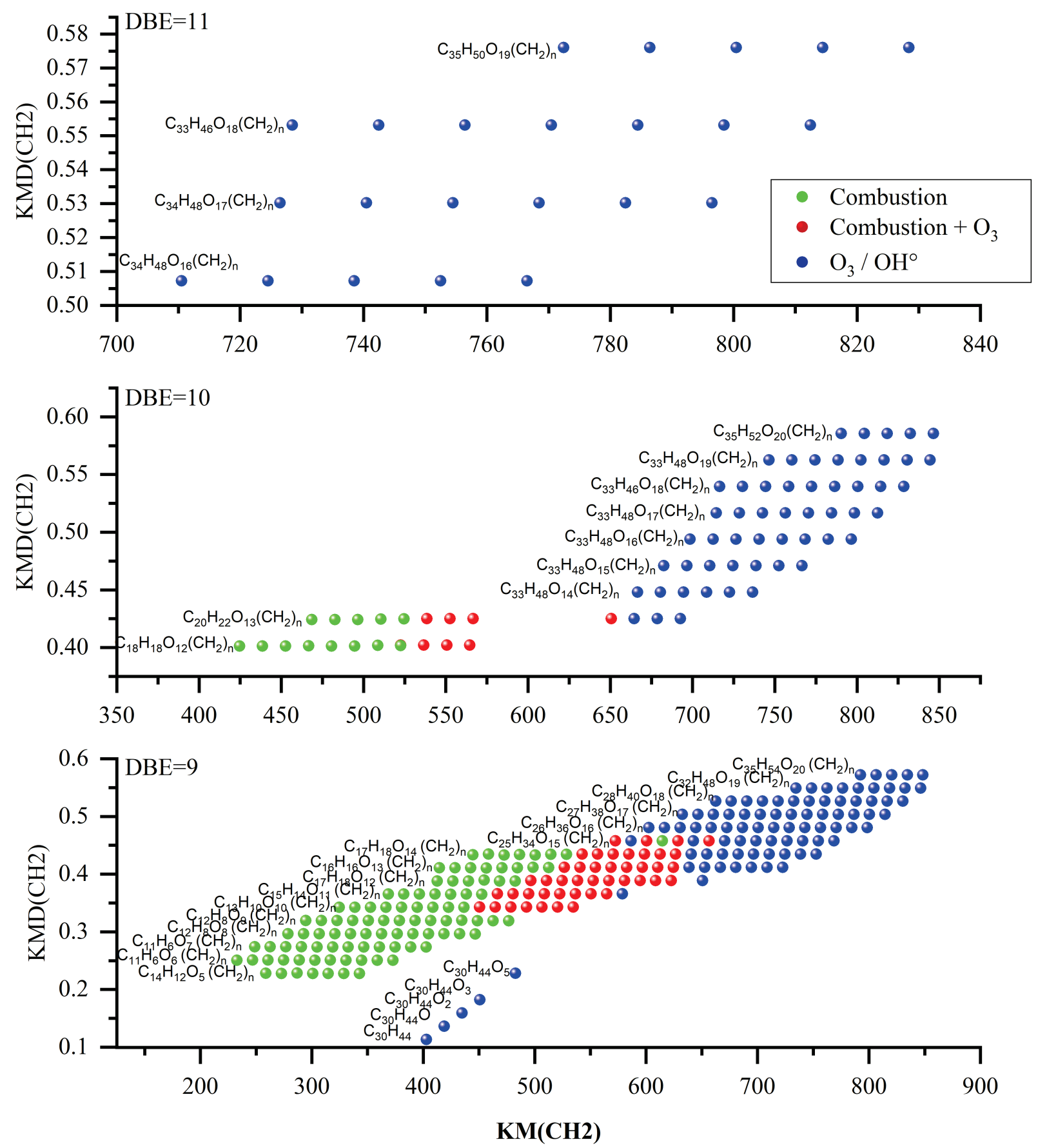

25 SI Figure 3. $\mathrm{CH}_{2}$ - Kendrick mass defect plots, DBE: 9-11 
Limonene : $\mathrm{C}_{10} \mathrm{H}_{16}$<smiles>C=C(C)C1CC=C(C)CC1</smiles>

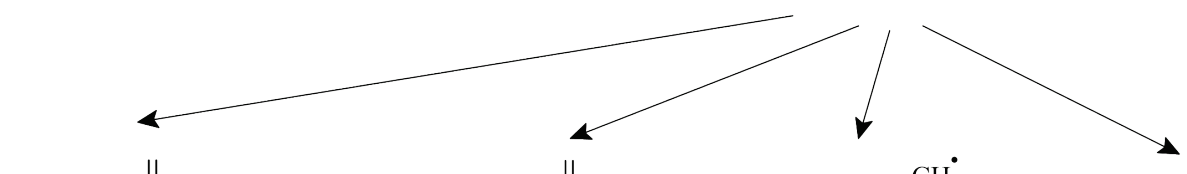<smiles>C=C(CO)C1CC=C(C)CC1</smiles><smiles>C=C(CO)C1CC=C(C)CC1</smiles><smiles>C=C(CO)[C]1CC=C(C)CC1</smiles>

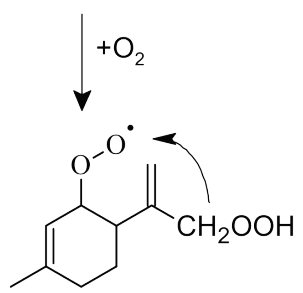<smiles>CC(C)O</smiles><smiles>C=C(C=O)C1CCC(C)=CC1OO</smiles><smiles>C=C(CO)C1CC=C(C)CC1OCCOO</smiles><smiles>[3H][13CH2][13CH3]</smiles><smiles>CC1=CCC(/C(=C/OOCCO)COO)CC1</smiles>
$+\mathrm{O}_{2}$<smiles>C=C(CO)C1(OCCO)CC=C(C)CC1</smiles><smiles>C=C(C)C1CC=C(C)CC1</smiles>

\section{Sites of $\mathbf{H}$-atom abstraction on limonene}

SI Figure 4. Examples of reaction mechanisms for the formation of KHPs from limonene and all the sites of H-atom abstraction on limonene that can give KHPs (18 isomers in total). 
<smiles>C=C(C=O)C1CCC(C)=CC1OO</smiles>

(1)<smiles>CC1=CCC(/C(C=O)=C/OO)CC1</smiles>

(4)<smiles>CC(=C=O)C1CCC(C)=CC1OO</smiles>

(7)<smiles>C=C(C)C1CC=C(C=O)CC1OO</smiles>

(10)<smiles>C=C(C)C1CC=C(C)C(=O)C1OO</smiles>

(13)<smiles>C=C(C)C1(OO)CCC(C)=CC1=O</smiles>

(16)<smiles>C=C(C=O)C1CC=C(C)CC1OO</smiles>

(2)<smiles>CC1=CCC(C(=C=O)COO)CC1</smiles>

(5)<smiles>CC(=C=O)C1CC=C(C)CC1OO</smiles>

(8)<smiles>C=C(C)C1CC=C(C=O)C(OO)C1</smiles>

(11)<smiles>C=C(C)C1CC=C(C)C(OO)C1=O</smiles>

(14)<smiles>C=C(C)C1CC=C(COO)CC1=O</smiles>

(17)<smiles>C=C(C=O)C1(OO)CC=C(C)CC1</smiles>

(3)<smiles>C=C(COO)C1CCC(C)=CC1=O</smiles>

(6)<smiles></smiles>

(9)<smiles>C=C(C)C1CCC(C=O)=CC1OO</smiles>

(12)<smiles>C=C(C)C1C(=O)C=C(C)CC1OO</smiles>

(15)<smiles>C=C(C)C1CC=C(COO)C(=O)C1</smiles>

(18)

SI Figure 5. 18 isomers of KHP potentially formed by oxidation initiated by the radical $\mathrm{OH}^{*}$ 


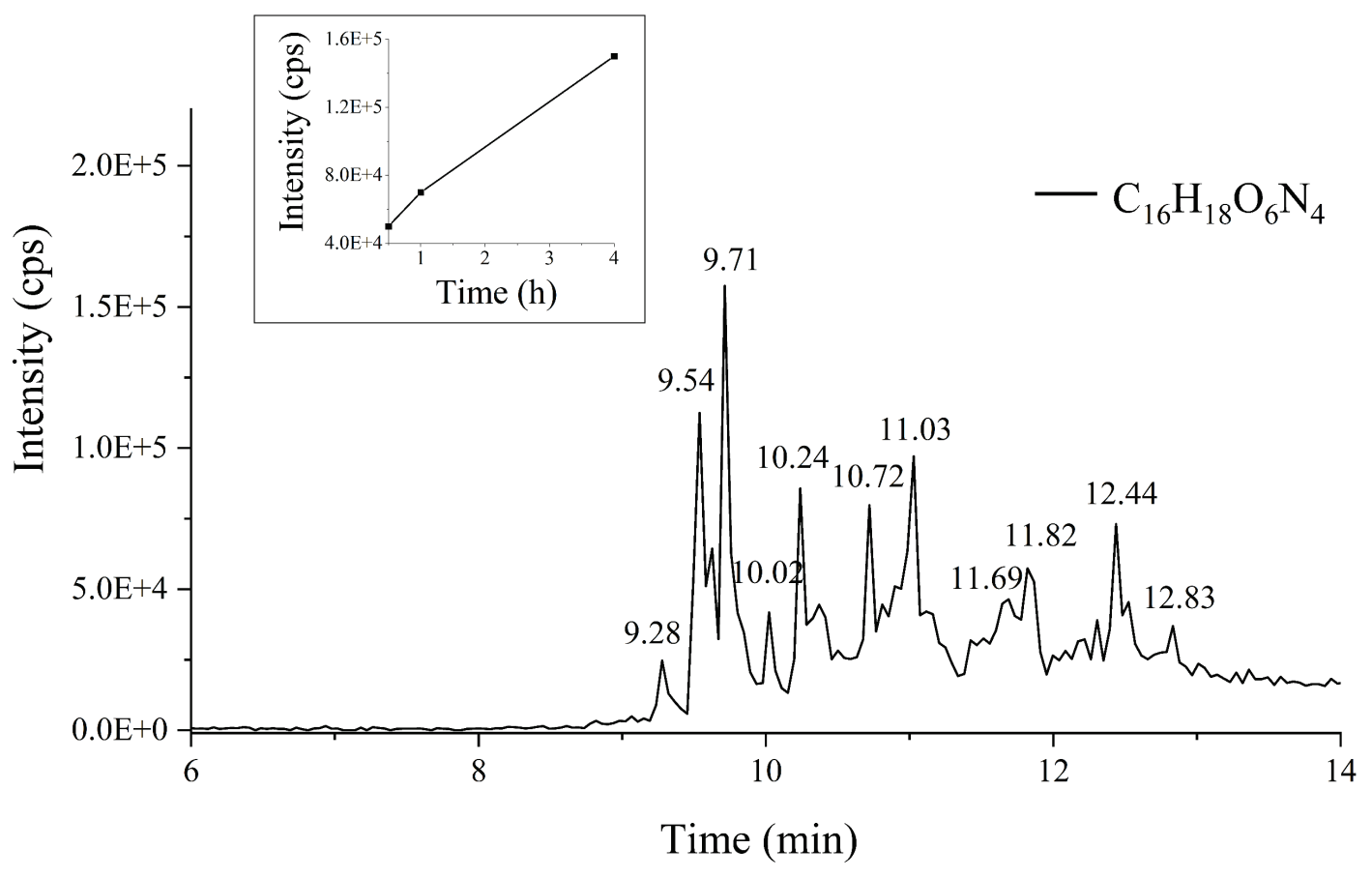

SI Figure 6. UHPLC-APCI neg (tSIM) spectrum of the compound $\mathrm{C}_{16} \mathrm{H}_{18} \mathrm{O}_{6} \mathrm{~N}_{4}$ from the reaction of KHPs with 2,4-DNPH, inset: increase of the peak intensity at $9.71 \mathrm{~min}$ as a function of reaction time with DNPH.

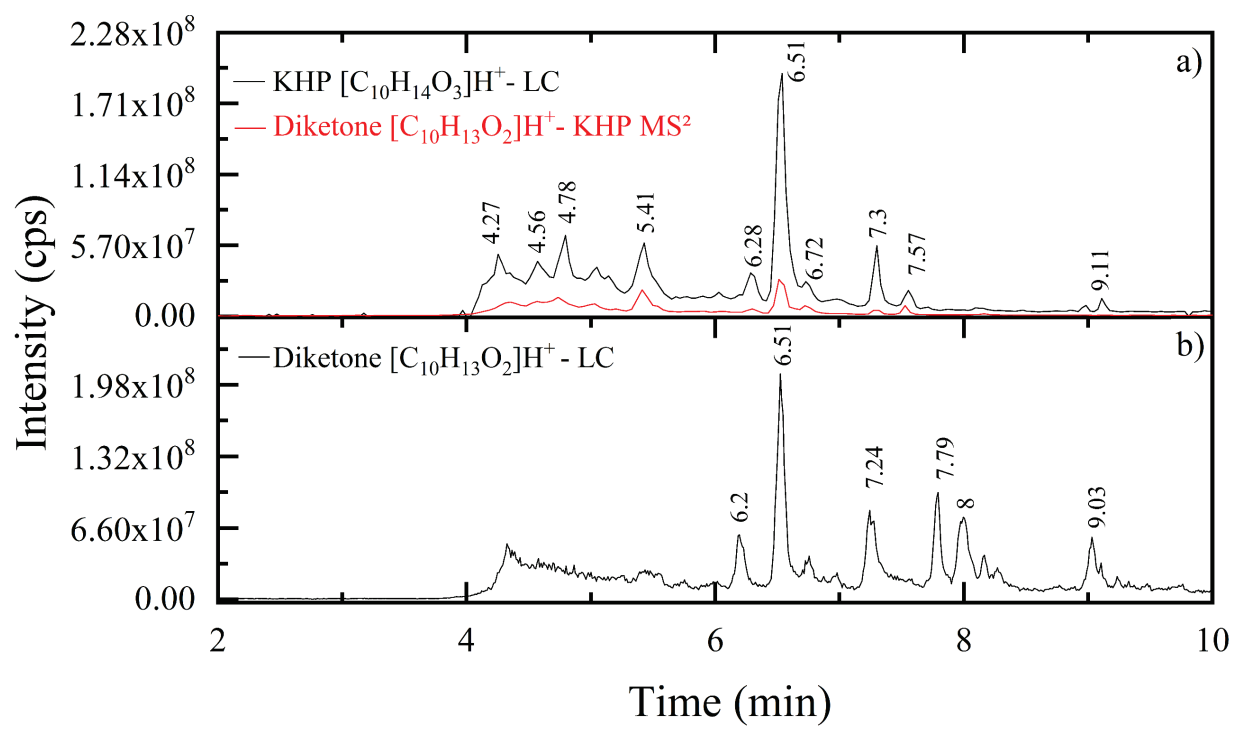

SI Figure 7. comparison of UHPLC profiles of diketones and KHPs. a) UHPLC KHPs with diketones signal extracted from the MS/MS of the KHP, b) UHPLC profile of diketones. 


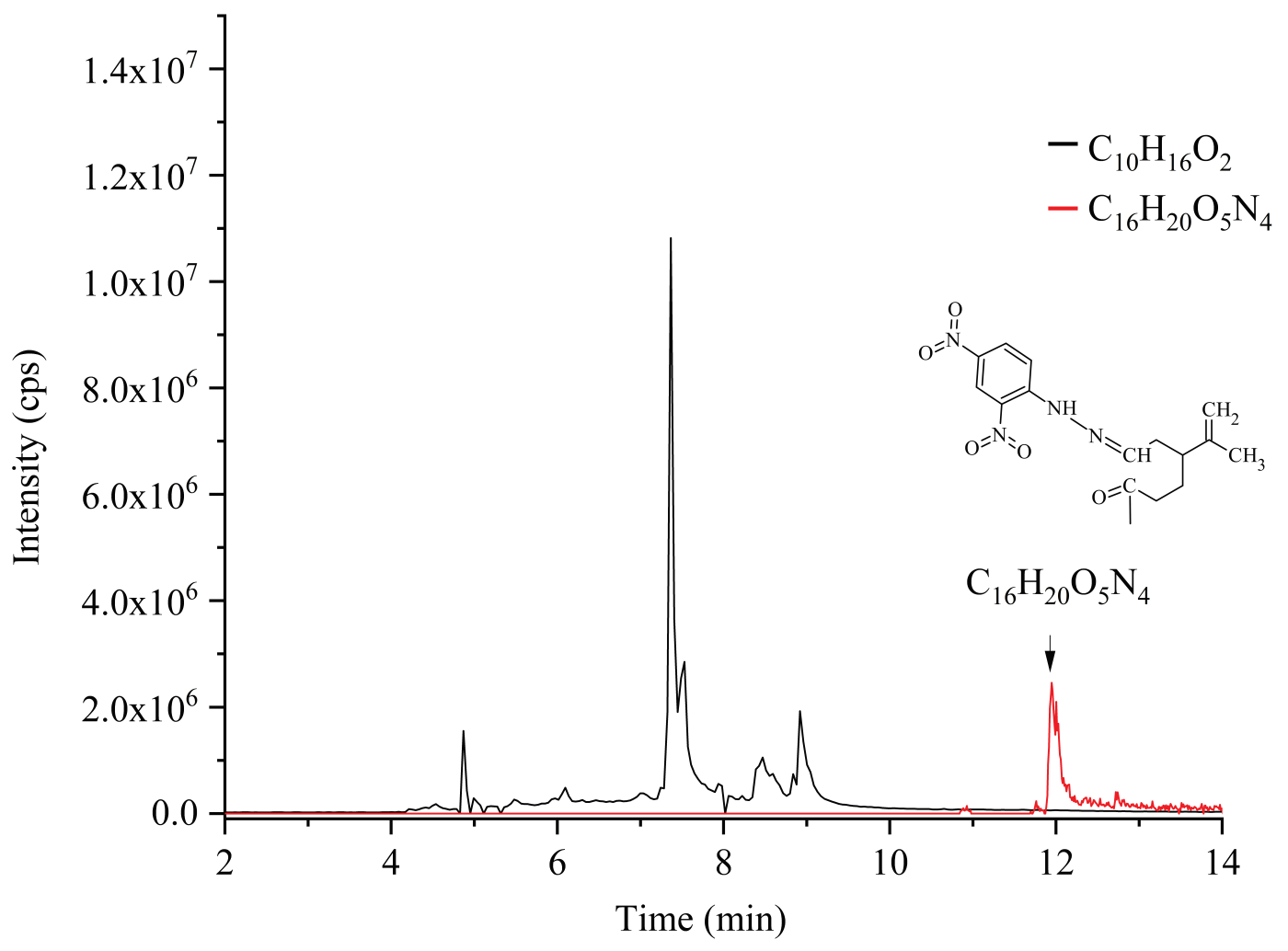

SI Figure 8. Comparison of the UHPLC profile (APCI - mode) of $\mathrm{C}_{10} \mathrm{H}_{16} \mathrm{O}_{2}$ (after adding DNPH) from the Waddington mechanism with that obtained by the addition of DNPH. 